\title{
Title: 'If parents are punished for asking their children to feed goats': Supervisory Neglect in sub-Saharan Africa
}

\section{Introduction}

During the passage of the Child Care, Protection and Justice Bill through the Malawian parliament in 2010, which domesticated the Convention on the Rights of the Child (CRC), Mr. Henry Phoya, MP for Blantyre Rural East opposing it, argued that:

"Malawi is located to the east of Central Africa and not to the east of Europe. We need to make some necessary departures from the way our friends in Europe do things...Are we serious, if parents are punished for asking their children to feed goats, assisting them on tobacco work or for bringing up their children in that way." (Cooleraid, 07.07.10)

Mr. Phoya's contestation of the normative relationship between parents and children, being legislated for through the introduction of a new child protection act, expresses objection to the imposition of an ethno-centric concept of parent/child relations with its genus in Europe rather than Africa. An expanding literature on the sociology of childhood has increasingly drawn attention to the globalisation of a very partial construction of childhood originating in the United States and Western Europe, most particularly the United Kingdom. As Head of Social Work at the University of Ghana during the 1990s it became apparent to me that students and practitioners alike were struggling to apply concepts of child protection derived from American and British authorities to the local context. The literature evidences the widespread nature of this problem both historical and contemporary in sub-Saharan Africa (Midgley, 1981; Rankopo \& Osei-Hwedie, 2011). Supervisory neglect, to which the Malawian MP above refers, is but one dimension of child maltreatment. However, data from a number of sub-Saharan countries suggest neglect is a major issue for child protection 
authorities with a higher incidence recorded than that for physical or sexual abuse (ANPPCAN, 2000; ANPPCAN-Uganda, 2012; The Star, 04.05.12). The incidence of unintentional injury, a key indicator of supervisory neglect, is almost seven times as high among African children as for those in Western Europe (WHO \& UNICEF, 2008: Figure 1.3). In relation to the economic circumstances of families, WHO (2002:80) warned, there is great danger in conflating parental poverty with parental neglect. A concern reiterated more recently by ANPPCAN-Uganda (2012:34). This study asks; how is child neglect constructed in sub-Saharan countries and how effectual is it in framing policy and practice around supervisory neglect?

\section{Methodology}

This explorative study based on secondary data analysis seeks to establish that the concept of child neglect is culture-bound and to demonstrate a significant disjunction between the concept of child neglect and the lived experiences of African families. Conducted in 2013 the study draws on country specific examples from national Demographic and Health Surveys which have now been compiled for the majority of sub-Saharan countries producing directly comparable information on population, income, living conditions and health (MeasureDHS, 2013). Exemplars from these Demographic and Health Surveys are used throughout the study and the degree to which they are representative can be cross-checked by visiting the MeasureDHS website. The comprehensive international research on accidental injuries to children conducted by WHO \& UNICEF (2008) comprises a major authority on the vulnerability of children to injury in the sub-Sahara and constitutes a key reference for this study. Anthropological and sociological literature has been identified through a series of key word searches on Swetswise, Google Scholar and ASSIA including: 'neglect and Africa', 
'neglect and sub-Sahara', 'childcare and sub-Sahara', 'childcare and Africa' 'child protection and Africa', 'law and child and Africa', 'family and Africa', 'family and sub-Sahara', 'kin and Africa', 'kin and sub-Sahara', 'parent and sub-Sahara', 'parent and Africa', 'mother and Africa', 'mother and sub-Sahara', 'father and Africa', 'father and sub-Sahara', 'child and work and sub-Sahara', 'household and Africa', 'household and sub-Sahara'. The reference lists from articles identified through online databases were used to identify further relevant research. Works relating only to specific localities or small ethnic groups were excluded. The anthropological studies cited explicate common economic arrangements, intergenerational dynamics, gender relations and family organisation found across the sub-Saharan region. The most cursory examination of the anthropological and sociological literature on the sub-Sahara will confirm the extent to which these identify typical conditions of living outside of the small middle-class elite confined to the cities.

\section{The Social Construction of the Child in Post-industrial Societies}

There is a broad consensus among European and American sociologists that the lives of those under sixteen years of age, and those over it, have over time become increasingly differentiated through technological advance, the advent of compulsory education and the growing emphasis on individualism (Ariès, 1960; Pollock, 1983; Cunningham, 1995). Children in the United Kingdom and the United States, who had in earlier centuries quickly assumed the responsibilities of childcare and productive work, in the nineteenth-century came under the scrutiny of welfare reformers who perceived them as ominously precocious and at risk of delinquency in the absence of close parental supervision and instruction. Their conviction that children from the impoverished masses required rescuing from employment, particularly on the street, and restoring to the 'care and protection' of an adult became an 
overarching political concern (James, et al., 2007:39-40; Wells, 2009:27-32). By the end of the nineteenth-century in both Britain and America new mores, codified in a raft of legislation, had largely banished children from the labour market, now regarded as the exclusive preserve of adults.

The ascribed place for children was to become the family home or school, both of which welfare reformers, and the child rescue movement they inspired, contended kept children safe from the corrupting influences and physical hazards of the street and other places of employment (James et al. 2007). Contemporaneously, the family became more narrowly defined as comprising a co-resident heterosexual couple with children living in a nuclear household. As children were increasingly excluded from community related activity and interaction, so they became the responsibility of parents rather than of broader society (Qvortrup, 2005). Childhood in industrial and later post-industrial societies evolved into: a distinct life stage set apart from adulthood; a state of need, vulnerability and dependency; a suspension of responsibility replaced by schooling and play; and a period requiring close guidance and supervision to ensure healthy moral, mental and physical development (Jenks,1996:123; James et al., 2007:16-17; Hendrick, 1997). The persistence of this essentially middle-class version of childhood is attributed to its high compatibility with the individuation required of post-industrial capitalism and neo-liberal formulations of the state (Aitken et al, 2006: Ansell, 2010). This construction of childhood not only defines what constitutes a good childhood, but acts as a standard against which to measure whether the parental care a child receives amounts to an adequate or neglectful upbringing. 


\section{The Dissemination of a Western Childhood}

Boyden (1997), Burr (2006) and Twum-Danso Imoh \& Ame (2012) all identify international law and multilateral agencies as the main disseminators of an ethno-centric construction of childhood originating in Western post-industrial countries. The CRC is an international treaty which entered into force in 1990, providing for the scrutiny of its implementation by the United Nations Children's Fund (UNICEF). Historically and contemporaneously the United Kingdom and the United States are the largest donors to UNICEF, giving them considerable influence over the policies of that multinational agency (UNICEF, 2012). Consequently, the CRC in conjunction with its overseeing multilateral agency constitute a primary conduit for the transmission of hegemonic notions of childhood in Africa (Ansell, 2010). All African countries are signatories, with the exception of Somalia. Its provisions are embedded in national statutes concerning child welfare and protection across the sub-Saharan region. The CRC grants comprehensive rights to children comprising inter alia the entitlement to: reside with their family; be accorded a standard of living adequate for their normal development; participate in formal education; have leisure; and be protected from maltreatment, including neglect, economic exploitation and hazardous or harmful work. Parents are required to offer 'appropriate direction and guidance in the exercise by the child of the rights recognised in the present Convention' (art.5). Moreover, 'the best interests of the child will be their basic concern' (art.18). The Convention does not impose any correlative duties on the child. The CRC construes children as dependents who require care, safety and protection to be provided by their parents. It articulates an essentially nuclear family structure with the proviso that other adult family members can legally deputise for parents (Ansell, 2010). However, States Parties are required to materially assist parents struggling to provide an adequate standard of living to meet the developmental needs of their children (art.27). This provision explicitly 
recognises that parents may not necessarily be financially able to create a physical environment conducive to their children's development.

At its inception, few African countries were involved in drafting the CRC which was dominated by the United States and Western European countries (LeBlanc, 1995:30). Thereafter, African governments criticised the Convention for failing to take account of the socio-economic situation in the sub-Sahara and the cultural heritage of African peoples (Veerman, 1992:182). Indeed, it was these criticisms which culminated in the development and adoption by the African Union of the African Charter on the Rights and Welfare of the Child almost a decade after the promulgation of the CRC. The African Charter, while replicating many of the provisions of the original Convention (as listed above), additionally places a set of duties upon children in relation to their family and community enumerated in article 31 . These include, 'subject to his age and ability...the duty to work for the cohesion of the family, to respect his parents, superiors and elders at all times and to assist them in case of need...to serve his national community by placing his physical and intellectual abilities at its service, to preserve and strengthen social and national solidarity'. This is a list of obligations which transcends the boundary of the nuclear co-resident household to embrace the kinship group and the wider society of which the child is deemed a member. The cooptation of a Western concept of childhood through the replication of many CRC provisions on the one hand and its rejection on the other through the addition of children's duties in the African Charter evidences the phenomenon of hybridisation noted by Ansell (2010). This is the process whereby African actors at the level of both policy and practice pragmatically adopt some Western formulations of childhood which suit their political and practical purposes at the time (often concerned with access to funding) and ignore others. Most sub-Saharan countries have now ratified the African Charter and introduced its provisions into their child welfare legislation (Philips, 2011:70). Consequently many national statutes incorporate two 
disparate constructions of childhood. One version construes children as entirely dependent, requiring protection and care from their parents while the other conceptualises them as holding duties to assist and meet the needs of others within an interdependent web of family relationships and community participation.

At the level of child protection policy and practice, the Africa Charter has exercised little influence because the dissemination of Anglo-centric conceptions of child abuse and neglect originating in the United States and the United Kingdom have historically shaped social welfare policy and social work in former British colonies, and continue to do so. African Schools of Social Work in Anglophone countries of the sub-Sahara remain highly reliant on British and American text books (Laird, 2008; Rankopo \& Osei-Hwedie, 2011). Laird (2011) demonstrates how Anglo-centric norms and methods of British and American social work are replicated by African social workers in their practice. Taken altogether, international law, UNICEF scrutiny and the dependence of African social workers on theories, methods and interventions conceived by American and British scholars has meant the imposition in Africa of a hegemonic conceptualisation of childhood originating in the United States and Western Europe (Jenks, 2005; Nsamenang, 2008). It follows that the trigger for State intervention in family life to protect children from neglect is predicated on this social construction of childhood. Definitions of supervisory neglect in the United States and the United Kingdom therefore articulate a particular and distinctive construction of childhood.

\section{Definitions of Supervisory Neglect}

According to the American scholar Coohey (2003:149) in her overview of studies on supervisory neglect, at the core of this concept is the failure of a parent to "provide the child 
with adequate protection from harmful people or situations'. Horwath (2007:35), based in the United Kingdom, draws on both American and British literature regarding child neglect to construct a table of supervisory neglect for each distinctive age group of children from infancy, to preschool, primary school and secondary school aged children. Among the most directly pertinent of these are:

- Infants being left in the care of another child

- Preschool children growing up in a home that is not 'child proof', being left alone or left to play outside unsupervised

- Primary school children left alone at home or left to play outside unsupervised, required to cook meals without guidance or expected to supervise younger children.

- Secondary school children left to their own devices or parents unaware of the movements of their children.

All of the above forms of neglect incorporate a construction of childhood as a state of dependency requiring fairly constant oversight and direction by an adult. Supplementing this age-related approach, Coohey (2003:150), who collated previous studies, resolves supervisory neglect into a five category typography which classifies parental behaviour. This comprises: did not watch child closely enough: inadequate substitute child care (including being left alone): failure to protect child from a third party; allowed or encouraged or forced child to engage in a harmful activity (including economic exploitation); and drove recklessly or while intoxicated. The younger the child, the greater the risk that a parent who did not watch closely enough or who arranged inadequate substitute care, will cause significant harm to that minor. Coohey's typography emphasises the essentialness of parental vigilance and proximity in delivering a legally acceptable standard of child care. It construes children as 
lacking in autonomy, susceptible to adverse pressures from adults and likely to be in danger without parental guidance.

Belsky's (1993) developmental-ecological model of child maltreatment focuses on the multiple contexts in which risk is situated and moves beyond the confines of family interactions. His model requires social work attention to: parental characteristics; child characteristics; parent-child interactions; community and social support; and the societalcultural context. However, further scholarship on Belsky's developmental-ecological approach has divided these different contextual levels into proximal risks (directly causal) such as parental inattention at the level of parent-child interactions and distal risks (indirect effect), of which poverty in terms of the societal-cultural context is one (Slack et al., 2003). Indeed, Slack et al., (2003:108) explicitly argue that the focus of professional attention should be on proximal and not distal indicators of risk. The downplaying of socio-economic factors relative to familial ones and the foregrounding of parental behaviour as opposed to that of other kinship members reflects an Anglo-centric nuclear family structure which is replicated in the wider scholarship on neglect.

Despite the positive correlation of poverty with child neglect in numerous studies (NSPCC, 2008) the attention of child protection agencies both in the United Kingdom and the United States remains on parental pathology on the grounds that not all parents on low income neglect their children and therefore neglect is indicative of family dysfunction rather than economic circumstance per se (Horwath, 2007; McSherry, 2004; Pierce \& Bozalek, 2004:818). This is notwithstanding the international definition of neglect adopted by WHO \& ISPCAN (2006:10) which stipulates that 'neglect includes both isolated incidents, as well as a pattern of failure over time on the part of a parent or other family member to provide for the development and well-being of the child - where the parent is in a position to do so'. The qualifier at the end of this definition advances the proposition that neglect requires 
deliberative acts of omission by parents or other family members who are socio-economically positioned to adequately cater for the child's needs. The contradictions engendered are examined for each of the main age groups of children identified by Horwath (2007:35) with the exception of secondary school children, as child protection services overwhelmingly focus attention on pre-teen children.

\section{The Home Environment and the Supervision of Infants}

As Demographic and Health Surveys across the region reveal, the vast majority of rural housing is of traditional building materials and construction which means that, in conjunction with the impoverished status of their occupants, most dwellings lack basic safety features such as railings to windows, stairs, balconies and roofs (MeasureDHS, 2013). As a result infants under one year of age in the low and middle income countries of Africa suffer fatal falls almost three times as often as those from the high income countries of Europe (WHO \& UNICEF, 2008:figure 5.2). In high income countries falls among infants are predominantly from cars or furniture. By contrast in the low income countries of the sub-Sahara they are from unprotected stairs and roofs, which are often flat and used for a variety of domestic activities (WHO \& UNICEF, 2008:107). Electrification in African countries is confined to cities and larger towns where it is subject to unpredictable and prolonged outages with the result that only $2-9 \%$ of families report using it to cook. There is no natural gas infrastructure in any sub-Saharan country. Consequently the predominant means of cooking among the majority of households in both rural and urban areas is by charcoal or firewood in an open hearth (MeasureDHS, 2013). This exposes children in Africa to a much greater likelihood of burns than in the United Kingdom or United States where cooking is largely by electricity or gas appliances. 
Precisely because burns are rarer in developed countries, in both the United States and the United Kingdom they are a well established sign of child neglect or abuse accounting for $10 \%$ of all forms of maltreatment. By contrast, in Africa burns occurring in the home are a common injury among adults and children alike, but constitute a significant cause of mortality and morbidity, among children. For example, in the Gambia burns accounted for $39 \%$ of all paediatric admissions (Christina, et al, 2003). However minors aged 1-2 years are at highest risk with infants under one year of age living in Africa suffering three times the number of fire related burns as the global average (Asuquo et al, 2009:433; Fadeyibi, et al, 2011:528; Hyder, et al., 2004). It is well established that the overwhelming majority of childhood burns occur in the home. House construction in sub-Saharan countries often comprises just a few rooms with one room commonly utilised for washing, cooking, eating and small scale economic activities. As a result young children are at high risk of exposure to hot water or fire (WHO \& UNICEF, 2008:86). An African practitioner dependent on authority from American and British texts will be mislead by the incidence of burns and scalds, attributing them to supervisory neglect rather than housing condition and the poverty which thwarts the mitigation of hazard. In their analysis of unintentional childhood injuries worldwide WHO \& UNICEF (2008) concluded that poverty was highly implicated in the elevated rate of falls and burns among younger children in Africa. Relative to the socioeconomic conditions of families, inadequate supervision was judged to play a minor role. In other words the risk factors deemed distal in America and Britain, (eg. family income, neighbourhood) are in fact proximate ones in a sub-Saharan country. Not only are they proximate, but they also raise questions about parental responsibility for child-proofing the home when the lack of public utilities and poor housing conditions are so inimical to child safety. 
Adults are plainly fettered by the economic circumstances and physical environment in which they must provide care and exercise supervision over a child. Since supervisory neglect assumes parental deliberation, it ignores the perforce nature of child related decision-making in a grossly impoverished context. Supervisory neglect in these circumstances is an inadequate construct for comprehending the nature of child maltreatment in the sub-Sahara. Societal neglect as a form of child maltreatment has received little attention in the British and American literature which is preoccupied by risk factors at household level (Smith \& Fong, 2004; Horwath, 2007:39). But it is most germane to the African context. Societal neglect is attributable to the political, social and economic forces which determine the day-to-day living conditions of families and the range of opportunities, services and support accessible to them. This concept of neglect re-directs attention away from parents or guardians to an examination of the policies and actions of governments, multinational agencies, bilateral donors, service providers and utility companies which cause harm to children through the conditions and constraints they impose on families. The housing conditions which are so hazardous to children and so difficult to guard against are predominantly aspects of societal neglect rather than parental neglect. Widespread impoverishment, defective buildings, low utility coverage and unsafe appliances are rooted in structural factors, not the routines of individual parents. Addressing these requires remedial action by States rather than families. These are macro level changes required of policy makers. At the micro level of practice, African social workers need to move away from reliance on Anglo-centric indicators of supervisory neglect which centre on frequency of injury and parental behaviour towards a broader assessment of living conditions in conjunction with very low income and how these impact on childcare. Addressing such issues will require practitioners to engage in advocacy and community organisation, activities closely aligned with social justice, but largely absent from the 
repertoire of American and British social workers within the child protection system (Frost \& Parton, 2010; Popple \& Leighninger, 2010).

\section{Supervision and Pre-School Children}

In most countries of the sub-Sahara over half the rural population are reliant on non-improved water sources (ie. water not supplied from a pipe, borehole or protected spring) which means water is obtained from rivers, lakes or dams (UNDP, 2011:Table 5). While urban households generally enjoy better access to piped water than those in rural settlements, as national surveys reveal large sections of urban populations do not have such access. For example in Nigeria, where exceptionally around $50 \%$ of the population live in conurbations, just $19 \%$ of urban dwellers can obtain water from a nearby pipe with $38 \%$ being reliant on more distance boreholes (NPC \& ICF Macro, 2009:Table 2.6). In Uganda just over 50\% of the urban population can avail of piped water (Uganda Ministry of Health, 2010:table 2.3). Water stored in cisterns in or near the home, because it is often being brought from relatively long distances, poses a further hazard to young children.

The increased risk posed to pre-school children by water in the sub-Sahara is reflected in the finding that they are twelve times more likely to be involved in a fatal drowning accident than are those living in the high income countries of Western Europe (WHO \& UNICEF, 2008:60). Moreover those aged 1-4 years in Africa are at higher risk than those of other age groups. In Europe most unintentional drownings are related to leisure activity, the highest numbers occurring in pools. However, for African children risk is associated with 'risky' water bodies which include lakes, rivers, ponds and dams. As water bodies are used for collecting water, washing clothes and bathing, children often frequent these localities (WHO 
\& UNICEF, 2008:66). Even when accompanied by an adult, due to the labour intensive nature of domestic and productive work, a parent or carer is unlikely to be able to have the child in sight at every point in time. Water bodies in Africa are largely unprotected and therefore highly dangerous, with the potential for a moment's parental inattention to result in a fatal drowning accident for a child.

Riesman (1992:37) observes that while the care of young children in Britain and America is conceptualised as a separate activity, among societies of the sub-Sahara it is usually integrated into the domestic and productive tasks of mothers, such as cooking, washing, crop cultivation, animal husbandry and small-scale income-generation. As a result the attention given to young children is within the context of household routines rather than through discrete periods of time devoted to play with the child as is typical of Western parenting (Monaghan, 2012:65-6). The shared cultural norm in most parts of the sub-Sahara that children of the locality are every adult's responsibility, means that quite young children are permitted much greater freedom to wander and explore than are their British or American counterparts (Gottleib, 2004). As reflected in s.31 of the African Charter, children are regarded as enjoying a communal relationship with adults of their locality, particularly elders, and not as relating solely to their parents within the private space of the family. Conversely, Coohey (2003:148) lists 'left with suitable caretaker but without consent or adequate planning' as a form of supervisory neglect in the United States, which by inference, positions the American child differently in relation to the wider community from that of their African peer.

Early childhood for the majority of African children is one characterised by greater mobility and autonomy, as children are expected to entertain themselves, walk un-aided and remain close-by while parents go about their daily routines (Gottleib, 2004). This diverges from the 
Western version of childhood perpetuated by the CRC, which advances the notion of a passive, vulnerable child requiring parental protection and guidance. According to the definitions of supervisory neglect adduced by Horwath (2007:35) and Coohey (2003:150), applying this standard, African parents appear neglectful, as they fail 'to watch closely enough' or attend to other tasks with the result that a child is 'alone or left to play outside unsupervised'. Parents preoccupied by the domestic and productive activities of marginal livelihoods will inevitably exhibit less proximity, vigilance and frequency of attention in relation to their children than their American and British counterparts. But the culturally bounded definitions of supervisory neglect collated by Horwath (2007) and Coohey (2003) ignore key characteristics of family organisation among sub-Saharan peoples. The diffusion of responsibility for child care among kin and adults living in the vicinity is a widely observed norm which commonly obviates the necessity or expectation of negotiated substitute childcare arrangements (Mathambo \& Gibbs, 2009). This is not to deny the dislocation of kinship structures and neighbourhoods caused by rural-urban migration, the AIDS epidemic and emigration in some parts of Africa (Foster, 2000; Hosegood, 2009).

Rather than focus on thresholds for supervisory neglect, deliberation should centre on the means of keeping children safe. Morrongiello \& Dawber (1998) researching in Canada identified three categories of prevention strategies employed by parents to protect their children from unintentional injury. These were: environmental (eg. removing the hazard or using safety equipment); parental (eg. increased vigilance) and child-based (eg. teaching children conduct rules or prohibiting certain behaviours). Environmental hazards are caused partly by domestic routines which actually take place outside of the home, such as water collection, and hence the exposure of young children to unmitigated dangers as in the case of unfenced water bodies. Partly they are due to poor housing and the indigent circumstances of parents unable to purchase safety equipment. Consequently, it is usually not feasible to 
remove the source of danger. Hazard is also created by societal neglect in the guise of inadequate regulation and enforcement of standards in relation to public protection. As regards parental vigilance, this will continue to vie with the attention demanded of mothers due to their extensive portfolio of tasks essential to meeting the basic needs of the household. Moreover, the emphasis on parental vigilance is itself a cultural construct which disregards the social organisation of kin groups and community in relation to childcare.

The third strategy employed by parents in the Canadian study to reduce the risk of unintentional harm to children was to teach them protective behaviours. This offers an approach consonant with an African construction of childhood, which contrary to that of the Western child, requires greater self-care at an earlier age. Even very young children can be taught basic dos and don'ts and assisted with practical skills to avoid common dangers. An emphasis on this dimension of parental care may be alien to British and American child protection systems, but it is highly consistent with the notion of the child as an active agent, capable of a range of autonomous actions. This suggests that the real debate to be had is around age-appropriate expectations in an inherently hazardous environment which reflect an African construction of the child. At a micro level this implies that social workers need to be better equipped to share effective teaching techniques for young children with adult kin. Moving beyond the narrow conception of parental supervision to support indigenous strategies for childcare should be a priority. Instead of censoring parents, particularly mothers, for inadequate vigilance, African practitioners must endeavour to support the wider kin and communal networks which traditionally share caring responsibilities with parents. 


\section{Supervision and Primary School Aged Children}

In most of the sub-Sahara, fathers, particularly in polygamous families, have historically not been involved in the upbringing of their children, and their role has been and continues to be predominantly confined to providing or supplementing material resources for the household (Nsamenang, 2010). Among many ethnic groups the household unit of mother and children is geographically separate from that of the father (as among matrilineal peoples) or else physically separate with mothers and young offspring residing in separate dwellings or rooms located off a courtyard as in compound housing (Nukunya, 2003; Hadley, 2005).

Contemporaneously, this has been accentuated by male migration from villages and provincial towns to find work elsewhere (LeVine, et al., 1994; Richter \& Morrell, 2008). Consequently, among many African societies fathers play a very circumscribed role in the lives of young children and are usually not available as caregivers due to geographic distance or cultural norms which ascribe gender roles and are prohibitive of men caring for children. Women therefore take on nearly all childcare responsibilities, the vast majority of domestic tasks and a substantial proportion of productive activities in low income households (Blackden \& Wodon, 2006; World Bank, 2011).

LeVine et al. (1994) and Gottlieb (2004) identify a range of typical practices among African mothers coping with time constraints in rural areas and in urban slums. Many of these rely on older female children taking care of younger siblings. Ascribed gender roles mean that girls aged 5-11 years are usually allocated responsibilities for the substitute childminding of siblings and are burdened with the greater share of domestic tasks. It is common to train children from a very early age in domestic routines and ancillary tasks linked to subsistence livelihoods. Children of both sexes may exercise considerable autonomy outside the confines of the home, often carrying responsibilities for looking after livestock, harvesting food or performing other domestic chores such as fetching water from or washing clothes at a source 
some distance from the dwelling. Such children, are exposed to unprotected water bodies, in the same way as pre-school children, but are often without an adult presence, putting them at even greater risk of fatal drowning (WHO \& UNICEF, 2008:60). Contribution to the survival needs of the household through petty trading or other commercial activities may also place quite young children in situations of minimal adult supervision (LeVine et al., 1994). Both primary school aged boys and girls in rural and peri-urban areas are required to engage in agricultural activity. This exposes them to another set of hazards. Boys have a higher incidence of falls than girls and in Africa this is associated both with greater risk taking as in other countries, but also agricultural and mining activity. Hence boys are more likely to suffer falls off ladders, from barns or trees and into ditches, pits, shafts and wells (WHO \& UNICEF, 2008:109).

What emerges from this overview of dominant African norms is the role of primary school aged children in contributing to the domestic and productive activities of the household and in caring for, training and playing with younger children (LeVine et al., 1994; Gottlieb, 2004; Penn, 2005; Prochner \& Kabirn, 2008). Thus in contrast to childhoods in post-industrial societies, in the sub-Sahara 'work is not considered to be the adults' domain where children 'help in', rather it is what everybody does for the mutual benefit of the family' (Hollos, 2002:176). In performing roles reflecting the correlative duties African children owe to the family, which often take them out-of-sight of adult family members, they exercise considerably more autonomy than most British or American children. The still common extended family form together with the diffusion of supervisory responsibility amongst adult kin means that the geographic distances between parents and children in most African households are much greater and correspondingly parental supervision is attenuated. Conversely, Horwath (2007:35) and Coohey (2003:150) identify parents being unaware of their children's movements and children being 'allowed or encouraged...to engage in 
harmful activity' as evidencing inadequate supervision and placing children at risk of significant harm. These formulations applied to African mothers are liable to make most of them into neglectful parents.

For households eking out a marginal living and mothers whose time is filled by multiple gender-ascribed demands, children's self-care and contribution to domestic and productive household tasks is vital to meeting the family's survival needs. This role of children is clearly envisaged in the African Charter, under art.31, but absent from the CRC. The construction of childhood which emerges from African family life for the majority, is one of greater independence in relation to self-care, but also of greater interdependence in terms of the reciprocity which informs exchanges of assistance and care between kin. However, it is their increased autonomy, compared to British and American children, which also exposes them to higher risk of accidental injury. The adult responsibilities of children in many African families begs the question as to who should be defined as a child. Art.2 of the African Charter defines a child as being under the age of 18 years. The CRC also categorises those under 18 years as children, but art. 1 adds the rider 'unless under the law applicable to the child, majority is attained earlier'. This permits a lower age. Most sub-Saharan countries have adopted the 18 years upper limit, however a small number, for example Malawi, define the child as being below 16 years. If children are construed as holding many adult responsibilities, to what extent might they indeed be defined as adults and therefore ascribed adult rights? As Bourdillon et al, (2010:23) argue in relation to working children, it is essential to move away from binaries of harmful and harmless child labour to acknowledging there is a continuum of children's work which at one pole offers substantial benefits to both them and their families while at the other it is so onerous and dangerous as to imperil children's welfare. Supervision should be re-conceptualised, at least in the sub-Sahara, within 
this type of scaling. One, which recognises the greater autonomy, agency and responsibility of many African children and therefore the reduced supervision they require.

This is not to argue that no policy changes or social work intervention is necessary. Children undertaking a range of domestic and productive activities are plainly exposed to greater hazard and this needs addressing. Rather than focussing primarily on parents and interventions to change their behaviour to ensure closer supervision of children, the Haddon Matrix is a holistic approach to reducing the risk of harm to children. This more pertinent framework was originally conceived by Haddon in the 1960s as an adaptation of public health approaches to injuries caused by road traffic accidents. The Haddon Matrix is now applied to a wide range of hazards, including those affecting children (Runyan, 1998; WHO \& UNICEF, 2008). It consists of a 12 cell matrix which plots risks before, during and after an injury or hazardous event against four dimensions, which are: the host (in this case child related factors); the agent (source of hazard); the physical environment and the socioeconomic environment.

To take the example of drowning, WHO \& UNICEF (2008: table 3.2) identify 68 discrete risk factors for children using the Haddon Matrix, of which just two relate to supervisory neglect, namely 'lack of supervision or child care' and 'reliance on peer or older child supervision'. Haddon (1973) also developed ten categories of countermeasures to reduce the risks identified in the matrix. To take just two examples in relation to drowning, the first involves preventing the creation of the hazard in the first place, such as introducing piped water, covering wells and water containers in and around the home. The second countermeasure is to make the person more resistant to damage by, for instance, teaching children water safety awareness and basic swimming skills or making available floatation devices. These few examples suggest that effective strategies to reduce risk to children must involve action at governmental, community and household level. With so many diverse 
environmental hazards daily encountered by children a focus on parental supervision is a blinkered child protection approach. The application of the Haddon Matrix to unintended injuries shifts the emphasis away from a linear and single cause of harm, such as parental neglect, to one which identifies a complex of multiple interacting causes originating in the wider environment of the child and family. As such it allows for the incorporation of societal neglect into child protection assessments. As discussed above, this will require policy level action. Although designed by an American scholar concerned with public health in the United States, the Haddon Matrix is a framework and not a prescriptive model. Potentially therefore it supports the identification of indigenous management strategies, for instance informal supervision by adults in the vicinity. This suggests that social workers focus their activity on wider social networks, when promoting the safety of children.

\section{Implications for Supervisory Neglect in Post-Industrial Societies}

This study though concerned with African childhoods, nevertheless raises questions for approaches to supervisory neglect in post-industrial countries. For example in the United Kingdom the global financial crisis of 2008 ushered in retrenchment of the welfare state with cuts to a raft of preventative services such as Sure Start, Children's Centres and youth services alongside substantial reductions in benefits which supplemented housing costs, low wages and disability (The Guardian 18.12.13). In conjunction with a sharp rise in the cost of living, this has culminated in greater child associated costs, a rise in child poverty, with 2.3 million in relative poverty and 2.6 million in absolute poverty and resort of the poorest families to charitable food banks (CPAG, 2013; Social Mobility \& Child Poverty Commission, 2013; The Guardian 18.12.13). At what point do allegedly distal risks become proximate factors in assessing supervisory neglect by parents? This of course is not a new 
conundrum. But as tax revenues shrink and governments reduce expenditure on public goods in the wake of the financial crisis, the detrimental impact on the socio-economic circumstances of low income families will intensify. This directly challenges the notion of supervisory neglect as a deliberative act by parents. Anglophone countries of both the global north as well as the global south need to re-visit a number of premises upon which their child protection systems rest. 


\section{References}

Aitken, S., Lopez Estrada, S. Jennings, J. \& Aguirre, L.M. (2006) Reproducing life and labor: global processes and working children in Tijuana, Mexico, Childhood, 13, 365-387.

ANPPCAN (2000). Awareness and views regarding child abuse and child rights in selected communities, Nairobi: African Network for the Prevention and Protection against Child Abuse and Child Rights.

ANPPCAN-Uganda (2012). A situational analysis of child abuse and neglect in Uganda, Kampala: African Network for the Prevention and Protection against Child Abuse and Child Rights.

Ansell, N. (2010). The discursive construction of childhood and youth in AIDS interventions in Lesotho's education sector: beyond global - local dichotomies. Environment and Planning D: Society and Space, 28, 791-810.

Ariés, P. (1962). Centuries of childhood: A social history of family life. Harmondsworth: Penguin Books.

Asuquo, M.E., Ekpo, R. \& Ngim, O. (2009). A prospective study of burns trauma in children in the University of Calabar Teaching Hospital, Calabar, south-south Nigeria. Burns, 35, 433436.

Belsky, J. (1993). Etiology of child maltreatment: a developmental-ecological analysis. Psychological Bulletin, 114(3), 413-434.

Blackden, C.M. \& Wodon, Q. (2006) (eds.). Gender, time use and poverty in sub-Saharan Africa, World Bank working paper no.73, Washington, DC: World Bank. 
Bourdillon, M. Myers, E.W., Levison, D. \& White, B. (2010). Rights and wrongs of children's work: childhood studies series, New Brunswick, NJ: Rutgers University Press.

Boyden, J. (1997). Childhood and the policy makers: a comparative perspective on the globalization of childhood, in A. James and A. Prout (eds.) Constructing and Reconstructing Childhood: Contemporary Issues in the Sociological Study of Childhood London and New York: RoutledgeFalmer.

Burr, R. (2006). Vietnam's Children in a Changing World New Brunswick, NJ: Rutgers University Press.

Christina, S., Saunno-Duanda, B. \& S.W. Bickler (2003). Pediatric trauma at a government referral hospital in the Gambia. WAM, 2, 287-290.

Coohey, C. (2003). Defining and Classifying Supervisory Neglect. Child Maltreatment, 8(2), $145-156$.

Cooleraid (07.07.10). Malawian government passes child protection laws. http://www.cooleraid.co.uk/articles/malawian-government-passes-child-protection-laws. accessed 11.10.11

CPAG (2013). The cost of a child in 2013. http://www.cpag.org.uk/content/cost-child-2013 [accessed 18.03.14].

Cunningham, H. (1995). Children and childhood in Western society since 1500. New York and London: Longman Publishing.

Fadeyibi, I.O., Mustapha, I.A., Ibrahim, N.A., Faduyile, F.I., Faboya, M.O., Jewo P.I. \& Ademiluyi, S.A. (2011). Characteristics of paediatric burns seen at a tertiary centre in a low income country: a five year (2004-2008) study. Burns, 37, 528-534. 
Foster, G. (2000). The capacity of the extended family safety net for orphans in Africa. Psychology, Health \& Medicine, 5(1), 55-62.

Frost, N. \& Parton, N. (2010). Understanding children's social care: politics, policy and practice, London: Sage.

Gottleib, A. (2004). The afterlife is where we come from: The culture of infancy in West Africa. Chicago: Chicago University Press.

Haddon, W. (1973). Energy damage and the ten countermeasure strategies. Journal of Trauma, 13, 321-331.

Hadley, C. (2005). Ethnic expansions and between-group differences in children's health: a case study from the Rukwa valley, Tanzania. American Journal of Physical Anthropology, $128,682-692$.

Hendrick, H. (1997). Children, childhood and English society 1880-1900. Cambridge: Cambridge University Press.

Hollos, M. (2002). The cultural construction of childhood: changing conceptions among the Pare of northern Tanzania. Childhood, 9(2), 167-189.

Horwath, J. (2007). Child neglect: Identification and assessment. Houndmills: Palgrave Macmillian.

Hosegood, V. (2009) The demographic impact of HIV and AIDS across the family and household life-cycle: implications for efforts to strengthen families in sub-Saharan Africa. AIDS Care 21(S1), 13-21. 
Hyder, A.A., Kashyap, K.S., Fishman, S. \& Wali, S.A. (2004). Review on childhood burn injuries in Sub Saharan Africa: a forgotten public health challenge. African Safety Promotion: A Journal of Injury and Violence Prevention, 2, 43-49.

James, A.L., Jenks, C. \& Prout, A. (2007). Theorizing childhood. Cambridge: Polity Press.

Jenks, C. (1996). Childhood. London and New York: Routledge.

Laird, S.E. (2008). Social Work Practice to Support Survival Strategies in Africa.

British Journal of Social Work, 38(1) 135-151

Laird, S.E. (2011). Social work with Children and Families in Ghana: Negotiating Tradition and Modernity. Child and Family Social Work, 16 434-443.

LeBlanc, L.J. (1995). The Convention on the Rights of the Child, United Nations lawmaking on human rights. Lincoln/London: University of Nebraska Press.

LeVine, R., Dixon, S. LeVine, S., Richman, A., Leiderman, P.H. Keefer, C.H. \& Brazelton, T.B. (1994). Child care and culture: lessons from Africa. Cambridge: Cambridge University Press.

Mathambo, V. \& Gibbs, A. (2009). Extended family childcare arrangements in a context of AIDS: collapse or adaptation? AIDS Care 21(S1), 22-27.

MeasureDHS (2013) Demographic and Health Surveys, http://www.measuredhs.com/publications/publication-search.cfm?ctry_id=39\&country, accessed 23.08.13.

McSherry, D. (2004). Which came first, the chicken or the egg? Examining the relationship between child neglect and poverty. British Journal of Social Work, 34, 727-733. 
Midgley, J. (1981). Professional imperialism: social work in the third world, London:

Heinemann.

Monaghan, K. (2012). Early childhood development policy: the colonization of the world's childrearing practices. In A. Twum-Danso Imoh \& R. Ame (eds.) Childhoods at the intersection of the local and the global (pp.56-74). Houndmills: PalgraveMacmillan.

Morrongiello, B. \& Dawber, T. (1998). Toddlers' and mothers' behaviours in an injury-risk situation: implications for sex differences in childhood injuries. Journal of Applied Developmental Psychology, 19 625-639.

NPC \& ICF Macro (2009). Nigeria demographic and health survey 2008. Calverton: National Population Commission \& ICF Macro.

Nsamenang, A.B. (2008). (Mis)understanding ECD in Africa: The force of local and global motives. In M. Garcia, A. Pence \& J.L. Evans (eds.) Africa's future, Africa's challenge: early childhood care and development in sub-Sahara Africa (pp.117-134). Washington D.C.: World Bank.

Nsamenang, A.B. (2010). Fathers, families, and children's well-becoming in Africa. In M.E. Lamb (ed.) The role of the father in child development (pp.388-412). Hoboken, NJ: John Wiley \& Sons NSPCC (2008). Poverty and child maltreatment. London: National Society for the Prevention of Cruelty to Children.

Nukunya, G.K. (2003). Tradition and change in Ghana. Accra: Ghana Universities Press.

Penn, H. (2005). Unequal childhoods. London: Routledge. 
Philips, C. (2011) Child-Headed households: A feasible way forward or an infringement of children's rights to alternative care? Amsterdam: Noordhoff.

Pierce, L. \& Bozalek, V. (2004). Child abuse in South Africa: an examination of how child abuse and neglect are defined. Child Abuse and Neglect, 28, 817-832.

Pollock, L.A. (1983). Forgotten children: Parent-child relations from 1500-1900.

Cambridge: Cambridge University Press.

Popple, P.R. \& Leighninger (2010). Social work, social welfare and American society. Upper Saddle River, NJ: Pearson.

Prochner, L. \& Kabirn, M. (2008) ECD in Africa: A historical perspective. In M. Garcia, A. Pence \& J.L. Evans (eds.) Africa's future, Africa's challenge: early childhood care and development in sub-Sahara Africa (pp.135-150). Washington D.C.: World Bank.

Qvortrup, J. (2005). Varieties of childhood in J. Qvortrup (ed.) Studies in modern childhood: society, agency, culture, (pp.1-20). Basingstoke: PalgraveMacmillan.

Rankopo, M.J. \& Osei-Hwedie, K. (2011). Globalisation and culturally relevant social work: African perspectives on indigenization. International Social Work, 54(1), 137-147.

Richter, L. M. \& Morrell, R. (2008). Fathering: The role of men in raising children in Africa: Holding up the other half of the sky. In M. Garcia, A. Pence \& J. Evans (eds.) Africa's future, Africa's Challenge (pp.151-166). Washington, D.C.: The World Bank.

Riesman, P. (1992). Find first your child a good mother: The construction of self in two African communities. New Jersey: Rutgers University Press.

Runyan, C.W. (1998). Using the Haddon matrix: introducing the third dimension. Injury Prevention, 4, 302-307. 
Slack, K.S., Holl, J., Altenbernd, L., McDaniel, M. \& Stevens, A.B. (2003). Improving the measurement of child neglect for survey research: issues and recommendations. Child Maltreatment, 8(2), 98-111.

Smith, M.G. \& Fong, R. (eds.)(2004) The children of neglect: When no-one cares. New York: Brunner-Routledge.

Social Mobility \& Child Poverty Commission (2013). State of the nation 2013: social mobility and child poverty in Great Britain. London: The Stationery Office.

The Guardian (18.12.13). The year government cuts changed the face of the welfare state. http://the guardian.com/society/2013/dec/18/review-of-year-cuts-nhs-welfare-charities [assessed 18.03.14].

The Star (04.05.12). Kenya: child neglect increases in Central Region, http://allafrica.com/stories/201205060107.html [accessed 08.02.14].

Twum-Danso Imoh, A. \& Ame, R. (2012). Introduction. In A. Twum-Danso Imoh \& R. Ame (eds.) Childhoods at the intersection of the local and the global (pp.1-14). Houndmills: PalgraveMacmillan.

Uganda Ministry of Health (2010). Uganda Malaria Indicator Survey 2009. Kampala:Uganda Ministry of Health.

UNDP (2011). Human development report: sustainability and equity a better future for all. New York: United Nations Development Programme.

UNICEF (2012). Top 20 Public and private Sector Donors to UNICEF in 2011 (US\$). www.unicef.org/parmo/files/compendium_page_4(1).pdf accessed 05.08.13. 
Veerman, P.E. (1992). The rights of the child and the changing image of childhood.

Dordrecht: Martinus Nijhoff Publishers.

Wells, K. (2009). Childhood in Global Perspective. Cambridge: Polity.

World Bank (2011). World development report 2012: Gender equality and development Washington, D.C.: The World Bank.

WHO (2002). World report on violence and health, Geneva: World Health Organisation.

WHO \& ISPCAN (2006). Preventing child maltreatment: A guide to taking action and generating evidence. Geneva: World Health Organisation.

WHO \& UNICEF (2008). World report on child injury prevention. Geneva: World Health Organisation and United Nations Children's Fund. 